ОСОБЛИВОСТІ ОСОБИСТІСНОї ЗРІЛОСТІ

TА КОМУНІКАТИВНОÏ КРЕАТИВНОСТІ

\title{
SPECIFICS OF PERSONAL MATURITY AND COMMUNICATIVE CREATIVITY
}

у статmі розглядаються результати теоретико-емпіричного дослідження індивідуально-психологічних особливостей комунікативної креативності в осіб із різними ступенями особистісної зрілості. Подаються теоретичні основи дослідження науковців, як українських, так і закордонних, які вивчали означену проблематику. Успішність спілкування, певний рівень розвитку креативності, рівень особистісної зрілості деякою мірою пов'язані один з одним, що демонструється не тільки розвиненими комунікативними якостями, а й мірою відповідальності людини за події власного життя, конструктивністю соціальної поведінки, саморегуляцією.

Аналіз теоретико-емпіричної літератури дозволив нам припустити, що особи з різними рівнями особистісної зрілості мають особливості комунікативної креативності. В емпіричному дослідженні брали участь магістри кафредри загальної та дифререниіальної психології Відділення перепідготовки фрахівців за магістерською програмою із психології Державного закладу «Південноукраїнський національний педагогічний університет імені К.Д. Уиинського» кількістю 64 особи віком 25-45 років. Як психодіагностичний інструментарій застосовувалися «Тест-опитувальник особистісної зрілості» та «Тест-опитувальник комунікативної креативності».

Кореляційний аналіз був здійснений за допомогою статистичної програми SPSS for Windows 17.0. Встановлено наявність значущих ( $p \leq 0,01),(p \leq 0,05)$ додатних кореляційних зв'язків між показниками комунікативної креативності й особистісної зрілості.

Надано психологічні характеристики осіб, що розрізняються різним ступенем особистісної зрілості. Кожному рівню особистісної зрілості відповідають особливості комунікативної креативності. Осіб із високим рівнем особистісної зрілості можна схарактеризувати як комунікативно креативних. Їхнє спілкування відрізняється легкістю, оригінальністю, незалежністю. У спілкуванні, у міжособистісних і соціальних відносинах такі особи проявляють креативність, творчий потенціал, це допомагає їм ефрективно й успішно вирішувати завдання цих відносин, робить їх цікавими співбесідниками та партнерами в різноманітних стосунках.

Ключові слова: особистісна зрілість, комунікативна креативність, спілкування, індиві- дуально-психологічні характеристики, особucmicmb.

The article considers the results of a theoretical and empirical study of individual psychological features of communicative creativity in individuals with different degrees of personal maturity. Theoretical foundations are presented research of scientists, both Ukrainian and Foreign, who studied this problem. The success of communication, a certain level of creativity development, and the level of personal maturity are somewhat related to each other, which is demonstrated not only by developed communicative qualities, but also by the degree of responsibility of a person for the events of their own life, constructive social behavior, and self-regulation.

The analysis of theoretical and empirical literature allowed us to assume that individuals with different levels of personal maturity have certain features of communicative creativity.

The empirical study was attended by masters of the Department of general and differential psychology of the Department of retraining of specialists in the master's program in psychology of the state institution South Ukrainian National Pedagogical University named after K.D. Ushinsky in the number of 64 people aged 25-45 years. As psychodiagnostic tools, the following were used: "Personal maturity test questionnaire" and "Communicative creativity test questionnaire".

Correlation analysis was performed using the statistical program SPSS for Windows 17.0. The presence of significant $(p \leq 0,01)$, $(p \leq 0,05)$ positive correlations between indicators of communicative creativity and personal maturity was established.

Psychological characteristics of individuals who differ in varying degrees of personal maturity are given. Each level of personal maturity corresponds to certain features of communicative creativity. People with a high level of personal maturity can be described as communicative and creative. Their communication is easy, original, and independent. In communication, interpersonal and social relationships, such individuals show creativity, creativity, and this helps them effectively and successfully solve the problems of these relationships, makes them interesting interlocutors and partners in various relationships.

Key words: personal maturity, communicative creativity, communication, individual psychological characteristics, personality. педагогічний університет імені К.Д. Ушинського

Сучасне життя, що наповнене об'єктивною непередбаченістю та різноманітними різновидами діяльності, вимагає від особистості творчої активності, уміння здійснювати пошук нових комунікаційних рішень, здатності реалізувати свій потенціал і досягати певного розвитку. Зміни, що сьогодні відбуваються в суспільстві, підвищують вимоги, особливо до розвитку комунікативних здібностей особистості, що виявляються не лише у сфері професійного, а й у міжособистісному спілкуванні.
Тому в умовах сучасності $€$ необхідність підвищення комунікативної компетентності у взаємодії людей. Бо низький рівень розвитку комунікативних якостей, внутрішньоособистісні конфлікти, невміння повноцінно інтегруватися в суспільстві, неспроможність вирішувати конфлікти, встановлювати взаємини з іншими тощо спричиняють низку особистісних психологічних проблем.

Також зростають вимоги до особистості професіонала, до тих властивостей, що забез- 
печують успішність спілкування і певний рівень розвитку креативності, до рівня соціальної й особистісної зрілості, що характеризується не тільки розвиненими комунікативними якостями, а й мірою відповідальності людини за події власного життя, конструктивністю соціальної поведінки, саморегуляцією.

Загалом комунікативна креативність розглядається як інтегральна властивість особистості, що характеризує її творчий потенціал. На думку сучасних психологів, комунікативна креативність $€$ стійкою властивістю особистості, яка містить комплекс інтелектуальних, емоційних та поведінкових компонентів, що сприяють нестандартному, нешаблонному розв'язанню проблем спілкування, прояву творчості у спілкуванні, генерації оригінальних ідей та засобів спілкування, вибору оптимальних для суб'єкта стратегій поведінки, що спрямовані на забезпечення успішної взаємодії з іншими людьми [8].

Згідно 3 поглядами деяких дослідників, комунікативна креативність - це здатність особистості нестандартно й ефективно вирішувати проблеми завдяки активізації комунікативного чинника, відкривати принципово нові або вдосконалені рішення того чи іншого комунікативного завдання. Особистість, що володіє високим рівнем комунікативної креативності, демонструє легкість у створенні численних варіантів поведінки, гнучкість та вміння трансформувати тактики реагування у використанні різноманітних прийомів поведінки, оригінальність, яка проявилася у створенні нестандартних способів виходу із ситуацій проблемного характеру [2].

Коли ми говоримо про комунікативну креативність, ми найчастіше маємо на увазі встановлення контактів між учасниками взаємодії, обмін повідомленнями, думками, задумами, рішеннями; спонукання активності партнера зі спілкування, спрямованої на виконання взаємовигідних дій; координацію - узгодження організації спільної діяльності; усвідомлення сенсу намірів, настанов партнера зі спілкування; вплив на емоції, наміри, рішення, думки; встановлення відносин у системі ділового спілкування; уміння переконувати партнера; вирішення конфліктів [2; 4].

Важливим $€$ розвиток цієї якості, оскільки вона забезпечує вміння вчитися, засвоювати нову інформацію, аналізувати складні ситуації, займатися складними видами інтелектуальної діяльності, ухвалювати нестандартні та відповідальні рішення, здійснювати управління, контроль планування, конструювання в різних середовищах.

У психології проблему прояву творчості у спілкуванні розглядали з різних підходів: креативність у сфері спілкування (У.В. Кала), вплив соціального середовища на формування креативності (Н.В. Хозратова, Н.М. Гнитко), у зв'язку із соціальним інтелектом (Є.І. Власова, А.Л. Галін, А.П. Коняева), як екстра-, інтроверсію (О.Н. Вороній), як особистісну категорію акмеології (Н.Ф. Вішнякова).

Можна сказати, що в даних умовах формується новий тип особистості, який реалізацією власних творчих здібностей також сприяє розвитку суспільства. Це такий ідеал людини, яка намагається творити власну долю, прагне не тільки до гармонійних відносин із собою, але й з оточенням, прагне творчого самовдосконалення і самостворення. Уміти бачити майбутнє, переконувати і надихати інших, керувати змінами, а також розробляти і здійснювати стратегії може людина, яка характеризується як зріла, зокрема особистісно зріла [12].

Особистісна зрілість визначається науковцями як ключове новоутворення віку, що корінним чином змінює попередню соціальну ситуацію розвитку; як рухома системна цілісність, яка розгортає, удосконалює, розвиває себе в соціально значущій діяльності, що реалізує багатоманітні соціальні стосунки [11]; водночас $є$ критерієм особистісного зростання та виявом особистісного потенціалу людини [12].

Проблемою особистісної зрілості цікавилися закордонні психологи в рамках гуманістичного напряму - А. Маслоу, К. Роджерс таінші; умежахдиспозиційноїтеорії-Г. Олпорт; а також російські науковці (К.О. Абульханова-Славська, Л.І. Анциферова, О.О. Бодальов, Д.О. Леонтьєв, А.О. Реан, В.М. Русалов), в українській психології - М.Й. Боришевський, Ю.З. Гільбух та інші.

Науковцями серед структурних компонентів особистісної зрілості розглядаються найбільш вагомі, прикладом яких $є$ : розширення почуття Я, теплота у стосунках до інших, емоційна безпека (прийняття себе), реалістичне сприйняття, самооб'єктивація - розуміння, гумор, єдина філософія життя (за Г. Олпортом); А. Маслоу називає аналогічні риси, як-от: безпристрасне сприйняття реальності; простота і природність поведінки; прийняття себе й інших людей; автономність і незалежність від культури й оточення; суспільний інтерес, опір окультурюванню [5; 6]. К. Роджерс [7] для визначення людей, які рухаються в напрямі самовдосконалення, увів поняття «людина, яка повноцінно функціонує», наділив її основними особистісними характеристиками, як-от: відкритість досвіду; прагнення жити повно і насичено в кожну хвилину існування; довіра до свого організму, що проявляється в довірі до своєї інтуїції та власного досвіду; емпірична свобода, яка виявляється у прагненні бути самостійною і відповідальною за свої вчинки; креативність. 
А.А. Реан визначає такі складові частини особистісної зрілості: відповідальність, терпимість, саморозвиток, позитивне мислення. у дослідженні Р.М. Шаміонова вказується, що особистісна зрілість складається з характеристик відповідальності в різних сферах діяльності, емоційної зрілості, самоконтролю поведінки, самостійності, адекватності самовідображення, високого рівня реалізованості подій життя, адекватності цілепокладання. Крім вищеозначеного, особистісна зрілість виявляється взаємопов'язаною з комунікабельністю, дотриманням соціальних норм, м'якістю, довірливістю, радикалізмом, упевненістю в собі, природністю [11].

Українська дослідниця О.С. Штепа [12] у процесі вивчення теми особистісної зрілості розглядає такі риси: відповідальність, децентрацію, заглибленість переживань, життєву філософію, толерантність, автономність, контактність, самоприйняття, креативність, синергічність. На думку автора, особистісна зрілість характеризується процесом внутрішньоособистісної трансформації, джерелом якої є потреба особистості в самоактуалізації і почутті ідентичності. Найголовнішою рисою визнається автономність.

К.О. Альбуханова-Славська зауважує, що потребою зрілої особистості $\epsilon$ усвідомлення себе ініціатором власного життя і необхідність послідовної реалізації нею своєї життєвої лінії. Згідно з Л.І. Божович, психологічно зрілою $є$ людина, яка здатна керуватися свідомо поставленими цілями, що визначає активний характер ії поведінки [1].

Цікавою в цьому зв'язку $є$ концепція Л.Г. Буряк, за якою «зрілість» - особлива якість особистості, яка не має жорсткої прив'язки до віку, а «є ознакою досягнення особистістю стану найвищої міри розвитку і вдосконалення» [3].

Особистісна зрілість $€$ результатом розвитку самої особистості, вона виступає тієї іï якістю, яка організуєжиттєвийшлях-ї̈ напрям, стратегії проходження, складну систему відносин особистості з навколишнім світом і собою. Водночас цей процес може мати як продуктивний, так і деструктивний характер, що утворює діалектичну єдність із переважанням продуктивних цінностей, мінімумом інфантильної поведінки і сприйняття (С. Кові, А. Маслоу, Е. Фромм). Тобто це результат особистісного росту $[5 ; 10]$.

Існує позиція, за якою особистісна зрілість $€$ центральним «ядром» аналізу структурних компонентів особистості. Особистісна зрілість розглядається як складне психологічне утворення, структуру якого становлять такі якості, як відповідальність у різних сферах життєдіяльності, емоційна зрілість, саморегуляція поведінки, автономність, адекватність само- ствердження, цілепокладання, високий рівень реалізованості подій життя [6].

Особистісна зрілість у дослідженні розуміється як результат дорослішання, тобто якість, залежна передусім від віку. Це поняття поширюється як на людський організм, так і на особистість, тобто на ті якості, які пов'язані із засвоєнням моральних норм, принципів міжособистісного спілкування, поведінки в колективі тощо. У структурі особистісної зрілості Ю.3. Гільбух розглядає п'ять аспектів, як-от: мотивація досягнення (прагнення до самостійності, ініціативності, до лідерства); ставлення до свого «я» (задоволеність собою); почуття громадянського обов'язку (професійна відповідальність, інтерес до суспільно-політичного життя, патріотизм); життєва настанова (розважливість, перевага інтелекту над почуттями); здатність до психологічної близькості з іншою людиною (уміння вислухати, відчувати емоційний стан та співпереживати іншій людині) [9].

Аналіз теоретико-емпіричної літератури дозволив нам припустити, що особи з різними рівнями особистісної зрілості мають особливості комунікативної креативності.

Для діагностики комунікативної креативності був використаний «Тест-опитувальник комунікативної креативності», авторами якого є О.П. Саннікова, Р.В. Бєлоусова [2; 8], який діагностує такі первинні біполярні показники комунікативної креативності, як: легкість у спілкуванні - трудність у спілкуванні (далі Л), схильність до самопрезентації - байдужість до самопрезентації (далі - Сп), незалежність залежність (далі-Н), конфліктність - покірність (далі - К), емоційна стійкість у спілкуванні емоційна нестійкість у спілкуванні (далі - Ece), схильність до маніпулювання - нехитрість (далі - М), експресивність - невиразність (далі - E), комунікативна компетентність комунікативна некомпетентність (далі - КК), вторинний - узагальнений (сумарний) показник комунікативної креативності (далі - ЗПКК).

Для діагностики особистісної зрілості «Тест-опитувальник особистісної зрілості», що був розроблений Ю.З. Гільбухом [8], що вивчає такі показники, як: мотивація досягнень (далі - МД), Я-концепція (далі - ЯК), почуття громадянського обов'язку (далі - ПГО), життєва настанова (далі - ЖН), схильність до психологічної близькості з іншою людиною (далі ЗБ), загальний показник особистісної зрілості (далі - 30)

У дослідженні взяли участь 64 особи віком від 25 до 45 років, магістри кафедри загальної та диференціальної психології відділення перепідготовки фахівців за магістерською програмою із психології Державного закладу «Південноукраїнський національний педагогічний університет імені К.Д. Ушинського». 
Відповідно до означеної мети дослідження отриманих у результаті діагностики емпіричних даних передбачало використання кореляційного аналізу, який був здійснений за допомогою статистичної програми SPSS for Windows 17.0. Досліджено й описано результати кількісного (кореляційного) аналізу. Встановлено наявність значущих $(p \leq 0,01)$, $(p \leq 0,05)$ додатних кореляційних зв'язків між показниками комунікативної креативності й особистісної зрілості.

Якісний аналіз був виконаний за допомогою методу «асів», який включив групування досліджуваних за певними ознаками показників особистісної зрілості, та методу «профілів», що дозволило встановити особливості комунікативної креативності в осіб із різним ступенем особистісної зрілості. Виокремлено 2 групи осіб за рівнем (високий і низький) загального показника особистісної зрілості: особистісно зрілі особи (гр. ОЗ max) і особистісно незрілі особи (гр. ОЗ $\mathrm{min}$ ).

Порівняння профілів, власні спостереження за досліджуваними, інтерпретації авторів опитувальників, а також дані, отримані з літературних джерел $[2 ; 4 ; 5 ; 6 ; 8]$, дозволили нам описати властивості комунікативної креативності осіб із різними рівнями особистісної зрілості.

Так, особам із високим рівнем особистісної зрілості властива легкість спілкування. Вони невимушено вступають у контакти 3 новими людьми, уміють ефективно й успішно виступати перед численною аудиторією, завжди можуть підтримати розмову, тобто вміють легко вливатися у взаємодію. Мають належний рівень знань і навичок для того, щоб встановлювати та підтримувати необхідні контакти з людьми. Виражена емоційна стійкість свідчить про емоційну зрілість, несхильність до обурення, уміння управляти власними емоціями, мобілізовувати та спрямовувати психічну енергію в конструктивне русло, на реалізацію планів та ідей, тобто проявляти наполегливість у досягненні мети. Вони демонструють критичне сприйняття поширених поглядів та думок. Мають власну позицією, уміють їі обстоювати. Вони схильні ігнорувати думки, якщо вважають їх неправильними, не підкорюються груповому тиску, або, якщо змушені, роблятьцезвеликимитруднощами. Унихєідея суб'єктивної доцільності, тенденція до створення власних законів, ігнорування безглуздих соціальних умовностей. Такі особи схильні до самопрезентації, артистичного самоподання, однак не переймаються ефектами, які справляють на оточення, не цікавляться стратегіями і тактиками управління враженнями, які в них викликають. Здатні адекватно самовиражатися у спілкуванні, можуть бути експресивними. До того ж їм не властива схильність до маніпулювання іншими.
Загалом таких осіб можна схарактеризувати як комунікативно креативних. Їхнє спілкування відрізняється легкістю, оригінальністю, незалежністю. У спілкуванні, у міжособистісних і соціальних відносинах такі особи проявляють креативність, творчий потенціал, це допомагає їм ефективно й успішно вирішувати завдання цих відносин, робить їх цікавими співбесідниками та партнерами в різноманітних стосунках. Тим самим вони збагачують себе й інших у живому процесі спілкування, у повсякденному житті, у професійному спілкуванні, якщо воно має місце.

Осіб із низьким рівнем особистісної зрілості вирізняє передусім свобода думок та вчинків, вони прагнуть до незалежності віл оцінок оточення, мало звертають увагу на враження, яке вони справляють на інших людей. Вони схильні до конфліктності. Водночас їм властиві покірливість, ригідність, бажання всіх задовольнити (навіть тоді, коли це заважає їхнім власним інтересам), нездатність обстоювати власну думку. В аспекті комунікативної компетентності їх можна схарактеризувати як людей із низьким ресурсом комунікативних засобів (знання, уміння, навички), отже, труднощами у сфері спілкування, у міжособистісних стосунках. Не досить виражена в них і схильність до маніпулювання. Однак ця характеристика не повністю відсутня, тобто цих осіб не можна вважати безхитрісними. Вони дещо здатні до управління власними емоціями та настроєм, але важко говорити про їхню емоційну зрілість. Зазнають деяких труднощів у налагодженні нових контактів, у самовираженні, у висловлюваннях своєї думки, саморозкритті. Їм важко вступити в розмову, якщо вона була розпочата без них, увійти у вже наявну групу.

Отже, у результаті якісного аналізу встановлено, що кожному рівню особистісної зрілості відповідають особливості комунікативної креативності. Ці особливості проявляються у своєрідному поєднанні показників комунікативної креативності.

\section{ЛITЕРАТУРА:}

1. Абульханова К.А., Березина Т.Н. Время личности и время жизни. Санкт-Петербург : Алетейя, 2001. 304 C.

2. Бєлоусова Р.В. Індивідуально-типові особливості комунікативної креативності : дис. ... канд. психол. наук: 19.00.01. Одеса, 2004.

3. Буряк Л.Г. Разноплановая деятельность как психологическое условие развития зрелой личности : автореср. дис. ... канд. психол. наук: 19.00.13. Петропавловск-Камчатский, 2005. 20 с.

4. Голованова Г.А. Коммуникативная креативность субъекта как фракт эффрективности группового решения задач : дис. ... канд. психол. наук: 19.00.01. Казань, 2003. 147 с.

5. Дідик Н.М.Просресійно значущі характеристики особистісної зрілості майбутніх психологів. 


\section{ГАБІТУС}

Проблеми сучасної психології : збірник наукових праць Кам'янець-Подільського національного університету імені Івана Огієнка, Інституту психології ім. Г.С. Костюка АПН України / за ред. С.Д. Максименка, Л.А. Онуфрієвої. Кам'янець-Подільський : Аксіома, 2010. Вип. 7. С. 190-206.

6. Меднікова Г.І. Особистісна зрілість: сутність та критерій. Вісник Харківського Національного педагогія університету імені Г. Сковороди. Серія «Філологія». 2012. С. 8-12.

7. Роджерс К. Взгляд на психотерапию. Становление человека. Москва: Прогресс, 1994. 480 с.

8. Санникова О.П., Белоусова Р.В. Оценка показателей коммуникативной креативности с помощью оригинальной методики. Наука і освіта. 2001. № 6. C. 52-54.

9. Тест-опросник личностной зрелости Ю.3. Гильбуха. URL: http:hrm21.ru/rus/tests/?action=show\&sid= 3296328.

10. Шамионов Р.М Личностная зрелость и профессиональное самоопределение в подростковом и юношеском возрасте: автореф. дис. ... канд. психол. наук: 19.00.13. Санкт-Петербург, 1997. 19 с.

11. Шорохова Е.В. Психологические аспекты проблемы личности теоретические проблемы психологии личности. Москва : Наука, 1974.

12. Штепа О.С. Особистісна зрілість: Модель. Опитувальник. Тренінг : монографія. Львів : Вид. центр ЛНУ імені Івана Франка, 2008. 210 с. 